\title{
Cancer stem cells, a fuzzy evolving concept A cell population or a cell property?
}

\author{
Aline Antoniou ${ }^{1, \dagger}$, Aline Hébrant ${ }^{1, \dagger}$, Genevieve Dom ${ }^{1}$, Jacques E Dumont ${ }^{1, *}$, and Carine Maenhaut ${ }^{1,2}$ \\ 'Institute of Interdisciplinary Research (IRIBHM); University of Brussels; Brussels, Belgium; ${ }^{2}$ Wellbio; School of Medicine; University of Brussels; Brussels, Belgium
}

'These authors contributed equally to this work.

Keywords: cancer, cancer hallmarks, stem cell, stemness, tumor

The cancer stem cells (CSC) hypothesis represents a pathological extrapolation of the physiological concept of embryonic and somatic stem cells. In its initial definition, it encompassed the hypothesis of a qualitatively distinct population of immortal cancer cells originating from somatic stem cells, which generate in xenotransplants by a deterministic irreversible process, the hierarchy of more differentiated finite lifespan derived cells, which constitute, themselves, the bulk of the cancer. These CSC would express specific biomarkers and gene expressions related to chemo- and radioresistance, stemness, epithelial-mesenchymal transition, etc.

No convincing congruence of several of these properties in one cell population has been demonstrated. The concept has greatly evolved with time and with different authors ("the plasticity of cancer stem cells"), leading to a minimal definition of cells generating a hierarchy of derived cells. In this article these concepts are analyzed. It is proposed that stemness is a property, more or less reversible, a hallmark of some cells at some time in a cancer cell population, as immortality, dormancy, chemo- or radioresistance, epithelial-mesenchymal transition etc. These phenotypic properties represent the result of independent, linked, or more or less congruent, genetic, epigenetic, or signaling programs.

\section{The Cancer Stem Cell Concept}

The concept of cancer stem cells (CSC) arose from the discovery that a majority of cells from some human leukemia (acute myeloid leukemia), at different stages of differentiation, originated from transformed undifferentiated pluripotent stem cell.1.-3 This led to the hypothesis, then the theory, that as in the normal somatic stem cells (SSC) and their derived tissues, a small population of cells, the cancer stem cells (CSC) would reproduce ad infinitum and generate the very diverse, limited lifespan, multilineage differentiated majority of cells in a cancer, called the derived population cells (DC) (Fig. 1). ${ }^{1,4}$ This was the concept of an aberrant stem cell system, a system gone awry. In agreement with such a scheme, CSC were assumed to originate from somatic stem cells (SSC) and to represent a minor, qualitatively distinct,

*Correspondence to: Jacques E Dumont; Email: jedumont@ulb.ac.be Submitted: 09/17/2013; Revised: 11/21/2013; Accepted: 11/21/2013

http://dx.doi.org/10.4161/cc.27305 eternal population, transforming deterministically and irreversibly in a limited lifespan, more or less differentiated hierarchy of derived cells that would constitute the bulk of phenotypically diverse cancer cell populations. ${ }^{1,3}$

Of course clinicians, frustrated by the only partial and transient success of their therapies, liked the idea. If the concept was valid, they would have to deal with one well-defined, but difficult to identify and study, population of cells responsible for a cancer. This would allow them to solve the problem of a cancer with one therapy well aimed at these cells. ${ }^{3,5,6}$ For industry the definition of different causal populations of cells in different patients would also allow proposing combinations of diagnoses and treatments for each patient. The experimental support of the concept was essentially that in xenotransplant experiments in immunologically deficient mice, only a minor fraction of the injected cells would generate tumors: the cancer stem cells. In suspension in vitro, this cell minority would grow in spheroids. Biomarkers were found to allow some purification of the CSC by cell sorting. ${ }^{1,7}$

\section{Proposed Attributes of the Cancer Stem Cells}

Over time quite diverse properties have been attributed to the postulated CSC. The origin of the CSC in the transformation of SSC seemed logical. ${ }^{3}$ In cell-shedding tissues, like the skin and mucosae, it makes sense, as only the SSC would have the time to accumulate the range of mutations necessary for cell transformation. However, if the first oncogenic event is to confer an increase in loco of the lifespan to the cells, this would not be necessary. In fact, in experiments in various models in which an oncogene was expressed all during the cells reproducing and differentiating sequence, the transformation took place at the stage of pluripotency as well as of unipotency and even later (for review, see ref. 8).

From the beginning of the CSC story, although, to our knowledge, it was not formally expressed, the concept of a minor population of cells, responsible for the progression and evolution of a cancer cast a doubt about the validity and interest of the work on epigenetics and transcription expression performed in bulk tumors, in which most of the cells would be degenerate or terminally differentiated. The fundamental results of such studies in our knowledge of the biology of cancer and on 


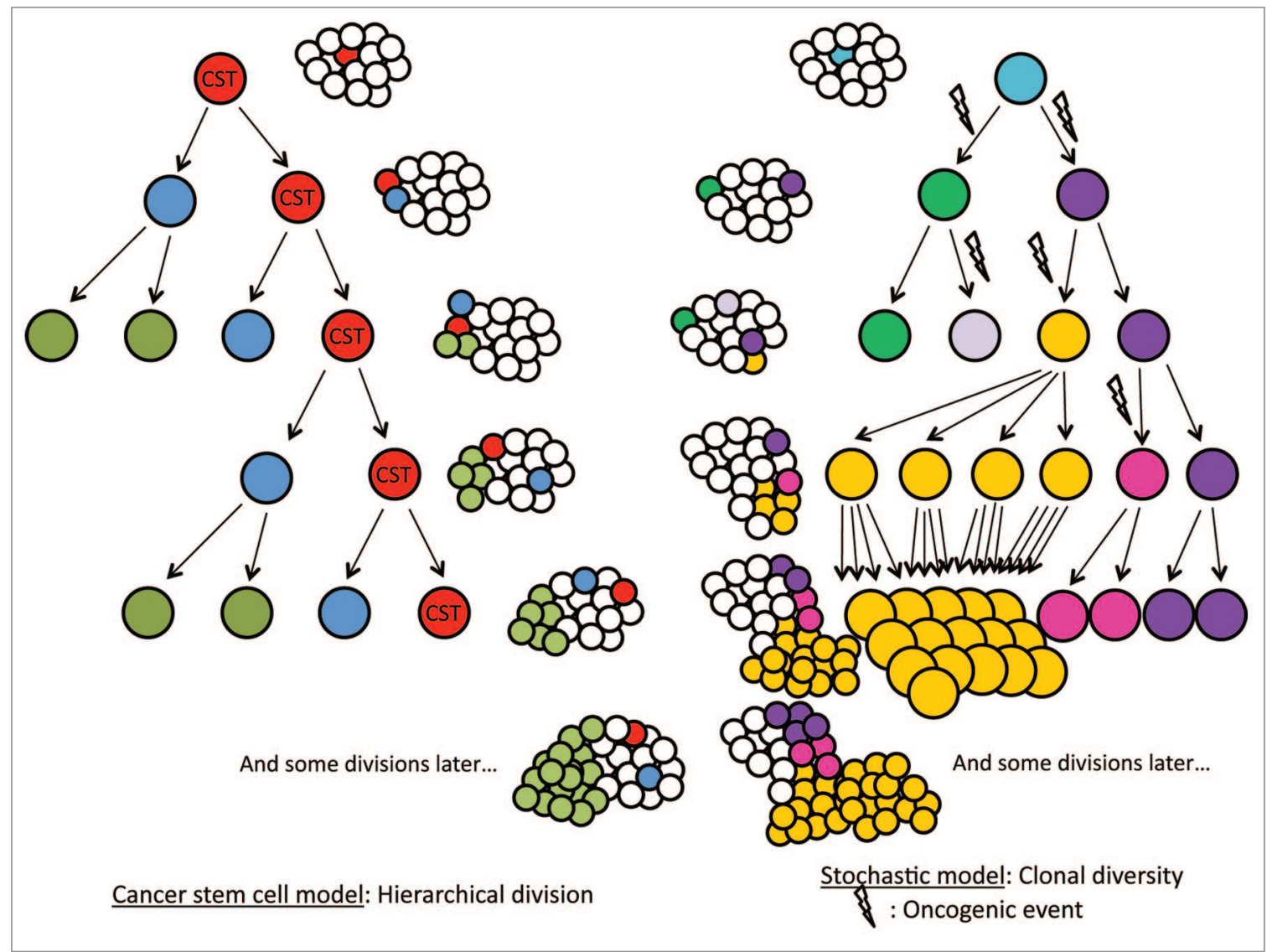

Figure 1. Cancer stem cell model compared with stochastic model.

prognostic diagnosis disagree with this concept: ${ }^{7,9-11}$ for instance gene expression allows to clarify and treat specifically breast and other cancers. ${ }^{9,12}$

The notion of CSC as a qualitatively distinct population of cells has been implicit and sometimes expressed. ${ }^{1}$ It is not supported by the various experimental tests applied to the cells (transplants, sphere formation in vitro, cell sorting with biomarkers, etc.) which always show overlaps with other cells (DC). ${ }^{7}$ On the other hand, if properly transplanted in fully immune-compromised mice, more than one-third of human melanoma cells generate tumors, i.e., would be CSC. ${ }^{13}$ Even in acute lymphoid leukemia, multiple subclones exist with a complex and nonlinear clonal architecture. ${ }^{14}$

Intratumor heterogeneity also bears against the concept of one population of cells generating all the cells in a cancer. ${ }^{15}$ This heterogeneity is both genetic and epigenetic and may also result from altered signaling. ${ }^{16}$ For example, the intratumor heterogeneity of human glioblastomas and other tumors suggests a multiclonal evolution compatible with the stochastic but not the CSC model. ${ }^{17-20}$

Another implied property of CSC is, as for SSC, the irreversibility of the transformation in more differentiated cells, DC. This property, in fact, is now questioned for SSC and embryonic stem cells (ESC), since the expression of just 4 transcription factors has now been shown to be sufficient to convert fully differentiated cells to an ESC state, and progenitor cells spontaneously revert to SSC upon crypt cloning. ${ }^{21,22}$ As for CSC-DC cell interconvertibility, the constant conversion of a few CSC cells in many multiplying DC is certainly easier to demonstrate than a rare reversion of these numerous DC into a tiny minority of CSC. The irreversibility is not valid in the case of human melanoma ${ }^{23}$ and is disproved by the regeneration over time in culture of a diversified cell population from purified $\mathrm{DC}^{24}$ and by the generation of cancer cells with stemness properties spontaneously ${ }^{25}$ following oncogene expression ${ }^{26}$ in primary $\mathrm{p} 53$-null mouse cells or metastasis ${ }^{27}$ or following EMT induction in cell lines. ${ }^{28}$ Conversely, CSC, EMT, chemoresistance characteristics are acquired by lung cancer cell lines after treatment with antiEGFR drugs. ${ }^{29}$

Linked to the concepts of irreversibility and qualitative nature of CSC to DC transformation are the implicit or explicit assumptions that this transformation is deterministic. The deterministic character of the conversion was even related to the semiconservative character of DNA replication, an asymmetric cell division, of one CSC to one conserved CSC and one derived cell. This deterministic character opposes all the evidence in favor of stochastic mechanisms of cancer cell diversity. ${ }^{15,30}$ This concept is, to our knowledge, no longer expressed in the literature.

Chemoresistance and resistance to radiation have also been attributed to CSC. ${ }^{31-33}$ Of course, again, if these properties 
applied only to CSC, the therapeutic problem would also converge on this cell population. This property could be ascribed and certainly would apply to a dormant population. However if CSC multiply fast (vide infra), it should be related to another attribute. Indeed ABCG drug transporters and enhanced DNA repair have been observed in some cancer cells. ${ }^{1,7}$ However, again, the congruence of these properties with the other proposed CSC properties has not been demonstrated.

The analogy between SSC and CSC has even been extended to the concept of the niche..$^{34}$ Quiescent SSC are often sequestered in a safe, protected environment, the niche. A similar concept has sometimes been proposed for CSC. In fact, rapidly dividing supposed CSC are often found in preferential sites of the tumor, e.g., near capillaries. ${ }^{35}$ However, it is a farfetched extrapolation to interpret these favorable spaces as preordained sites, the niche. It seems simpler, even if less spectacular, to assume that an oxygenrich environment is more favorable for proliferation.

The use of biomarkers, allowing purifying, to some extent, CSC by cell sorting, has greatly contributed to the expansion of the field (e.g., CD44, CD133, ALD4). The panel of biomarkers used is different from one type of cancer to another. ${ }^{34}$ However, the validity of these biomarkers is cast in doubt by one disturbing fact. Although the question was asked several times in reviews, sequential cell sorting purifying CSC having all the properties and biomarkers of CSC has, to our knowledge, never been reported. ${ }^{16}$ In fact, the fraction of cells expressing one biomarker in breast CSC was not expressing another biomarker. ${ }^{36}$ With this and other methodologies, the separation of a proportion of cells by any criterion (whether seeding capacity, sphere formation, biomarker-based cell sorting, etc.) assumes that the property used is stable in tissue, i.e., cells in a negative phase of any fluctuating property (e.g., epigenetic, transcriptional, feedback linked control) will be missed. Of course this would not apply to a qualitatively irreversibly well-defined CSC population! In fact, any criterion used to define a cell population applies to those cells that answer it at the moment it is used. Finally, the specificity of these biomarkers has never been demonstrated. In fact some of them are good markers for normal tissue adjacent to a tumor. ${ }^{37}$

In the CSC literature, there has always been an ambiguity with regard to the proliferative or quiescent state of the CSC cells. ${ }^{30}$ In fact, the normal stem cell models have opposite characteristics: while ESC are strongly proliferative, SSC were, until recently, considered as rarely dividing cells. ${ }^{1}$ This was even used, for some SSC, as a criterion to identify them by the remnants of their DNA labeling. ${ }^{38}$ However, even for some SSC, it is now accepted that there may be 2 interconverting populations of SSC, one quiescent, one proliferating. ${ }^{31}$ The concept of quiescent CSC, while useful to explain the continued presence of cancer cells after therapy, does not fit in with other proposed properties of the supposed CSC: e.g., the spheroid formation assay, which allows purification to some extent CSC by selective growth, the SP cells which extrude drugs and which would soon disappear if they reproduced less than other cancer cells..$^{39,40}$ Moreover, various supposed CSC were shown to be highly proliferative. ${ }^{30,36,41,42}$ This concept is even more incompatible with the existence of CSC in cell lines: they would soon disappear. ${ }^{7}$

\section{Present State of the Literature}

With the progressive abandonment of claimed SSC and ESC properties, the CSC concept has evolved toward the existence of very competitive cancer cells continuously generating a majority of cells, less active, degenerating, and with limited reproduction capacity and even survival potential. ${ }^{34}$ This was the simple conclusion of Tubiana group $40 \mathrm{y}$ ago. ${ }^{43}$ It explained the important discrepancy between cell proliferation rates, evaluated by tritiated thymidine labeling of biopsies, and the measured in vivo tumor growth rate in breast cancers. This has been confirmed and visualized more directly by the more sophisticated method of linear tracing in experimental models in which the expression of an oncogene is induced at a chosen time and the consequences examined in the cell of origin of the tumor and in its successive descendants. ${ }^{44-46}$ The hierarchy of progressively more diversified tumor phenotypes, in fact, reproduces the well-known behavior of cells in developing metastases ${ }^{47}$ It is easily explained by the fact that most genetic (and probably epigenetic and others) events, when not neutral, lead to loss of competitiveness and much more rarely to an increase of competitiveness. ${ }^{48,49}$ In the case of cancer cells, as in ESC, the default state of the cell is differentiation, which may be due to loss of the stem cell program. ${ }^{3,50}$ In this framework, the CSC are just the fraction of most competitive cells in a cancer. It has been proposed to call them "stemloids". 39 However this concept is opposite to the hypothesis of a dormant population of CSC.

The different characteristics of so-called CSC do not necessarily coexist in the same cells. In fact, in several cases, cells that exhibit the biochemical markers of CSC are precisely not those that have the functional characteristics of sphere formation and tumorigenicity. ${ }^{51}$ The progressive simplification and evolution of the definition of CSC has been called euphemistically "a paradigm shift" and described as "the plasticity of CSC",52 "plasticity and clonal diversity of CSC", 53 "stemness as a flexible quality of cancer cell", ${ }^{27,54}$ etc. This constantly evolving definition has of course made the concept an elusive target for critical analysis. ${ }^{739,55}$ This conclusion is apparent, but not explicit, in other reviews. 3,15,34,53,56-58 Reprogramming stemness with NANOG and LIN28 may even reverse back the cancer character of sarcoma cells ${ }^{59}$ and, as shown more than $30 \mathrm{y}$ ago, the oncogenic potential of teratocarcinoma cells after grafting in blastocysts was reversed. The question therefore is: why continuing to use a misleading terminology? Is stemness not rather a property or phenotype that cancer cells may have, lose, and even acquire, like the other hallmarks of cancer, rather than the definition of a distinct population of cells? $?^{15,16,60,61}$

\section{Necessity of the Use of a Well-Defined Terminology}

In the present stage of uncertainty, the use of a precise welldefined terminology based on operational definitions would certainly clarify a literature confused by the use of the variously defined, constantly changing, fuzzy concept of CSC. The literature proposes such definitions: the cell of origin of a tumor (COT) is the one in which the original oncogenic event(s) 
occurred. ${ }^{8,57,62}$ The tumor initiating cell (TIC) is the cell that first showed the signs of transformation and initiated the tumor. It may not necessarily be the cell of origin: for instance, in linear tracing experiments the expression of the oncogene begins at the time chosen by the experimenter, but the transformation may occur at a later stage of the cell evolution (e.g., pluripotent cell). ${ }^{45}$ Cell of origin and TIC identity may bear on the phenotype of the resulting tumor. ${ }^{63}$ The tumor propagating cell (TPC) $)^{7,64}$ or cancer repopulating cell ${ }^{57}$ is the already committed cancer cell that is able to generate a tumor; for instance, in xenotranplants the cancer cell transplant does not initiate a cancer, it merely propagates it in a new site. Xenotransplants can be orthoptic (implanted at the site of the naturally occurring tumor) or ectopic (other sites). In situ and metastatic propagations should be distinguished.

"Cancer stemloids" would be the rapidly dividing, evolving cells of the cancer that generate the slower dividing, more differentiated "derived cells". ${ }^{39}$ Non-proliferating cancer cells that may redevelop in a cancer are dormant cells. This is a phenotype adopted for example by disseminated tumor cells, which at some time may explode in metastatic growth. ${ }^{65}$ In some cases, this is conditioned by the vascular microenvironment. ${ }^{66}$ "Biomarker characterized cells" (e.g., CD44++ CD24- cells, CD133+ cells, aldehyde dehydrogenase-expressing cells $\mathrm{ADH}^{+}$, etc.) should be called by their operational property, e.g., CD133 cells etc. Any claim to the full congruence of such definitions and programs should be proved. Cancer cells expressing an embryonic stem cell program, essential for maintaining dedifferentiation, and thus repressing the expression of the various differentiation programs that constitute the hierarchical descendants of these cells, are just cells expressing the stemness ESC program or pluripotency. Such a program may totally or partially overlap with other programs developed at some time by cancer cells, such as the epithelialmesenchymal transition (EMT). ${ }^{30}$ The 3 programs stemcellness, EMT, and radioresistance can be induced together by EMT inducing transcription factors (e.g., ZEB) in some cell lines. ${ }^{67,68}$

\section{Conclusion}

Thus, stemness would be a hallmark or a phenotype of cancer, probably linked to dedifferentiation, characterizing in a cancer some cells at some time. There would not be a separate population of CSC, just as there is no population of cancer EMT cells! The stemness could be a functional (transplant, hierarchy, etc.) or/and a biochemical (expression of ESC inducing transcription factors) property or hallmark. In fact, the state of any given cell in a tumor results from the programs expressed, at the time of the investigation, by this cell. This is more or less reversible depending of the mechanisms involved, genetic, epigenetic, or resulting from a signaling equilibrium. ${ }^{16}$ Presumably, a large majority of tumor cells with a differentiated phenotype and a limited lifespan will never revert to active dedifferentiated phenotype.

Of course, if to treat a cancer one had to target one population of well-defined CSC, the aim of therapeutic research should be to find drugs for this target. This has been tried: ${ }^{6}$ salinomycin as the candidate CSC drugs. Our and other analyses bear against this approach. ${ }^{39}$ On the other hand, if, as the evidence suggests, we have to deal with a constantly evolving diversified population of cells, the best therapies should then, as in the case of HIV, be simultaneous multi-target therapies: hit most of the cells at the same time, not allowing cells already resistant to one therapy to survive and permit some of them to acquire later resistance to another therapy.

\section{Disclosure of Potential Conflicts of Interest}

No potential conflicts of interest were disclosed.

\section{Acknowledgments}

The authors thank WELBIO, the Fonds National de la Recherche Scientifique (FNRS) and the "Plan Cancer" for the support of their research.

\section{References}

1. Dalerba P, Cho RW, Clarke MF. Cancer stem cells: models and concepts. Annu Rev Med 2007; 58:26784; PMID:17002552; http://dx.doi.org/10.1146/ annurev.med.58.062105.204854

2. Lapidot T, Sirard C, Vormoor J, Murdoch B, Hoang T, Caceres-Cortes J, Minden M, Paterson B, Caligiuri MA, Dick JE. A cell initiating human acute myeloid leukaemia after transplantation into SCID mice. Nature 1994; 367:645-8; PMID:7509044; http:// dx.doi.org/10.1038/367645a 0

3. Clarke MF, Fuller M. Stem cells and cancer: two faces of eve. Cell 2006; 124:1111-5; PMID:16564000; http://dx.doi.org/10.1016/j.cell.2006.03.011

4. Hirschmann-Jax C, Foster AE, Wulf GG, Nuchtern JG, Jax TW, Gobel U, Goodell MA, Brenner MK. A distinct "side population" of cells with high drug efflux capacity in human tumor cells. Proc Natl Acad Sci U S A 2004; 101:14228-33; PMID:15381773; http://dx.doi.org/10.1073/pnas.0400067101

5. Boman BM, Wicha MS. Cancer stem cells: a step toward the cure. J Clin Oncol 2008; 26:27959; PMID:18539956; http://dx.doi.org/10.1200/ JCO.2008.17.7436
6. Gupta PB, Onder TT, Jiang G, Tao K, Kuperwasser C, Weinberg RA, Lander ES. Identification of selective inhibitors of cancer stem cells by high-throughput screening. Cell 2009; 138:645-59; PMID:19682730; http://dx.doi.org/10.1016/j.cell.2009.06.034

7. Maenhaut C, Dumont JE, Roger PP, van Staveren WC. Cancer stem cells: a reality, a myth, a fuzzy concept or a misnomer? An analysis. Carcinogenesis 2010; 31:149-58; PMID:19858069; http://dx.doi. org/10.1093/carcin/bgp259

8. Blanpain C, Simons BD. Unravelling stem cell dynamics by lineage tracing. Nat Rev Mol Cell Biol 2013; 14:489-502; PMID:23860235; http://dx.doi. org/10.1038/nrm3625

9. Sotiriou C, Pusztai L. Gene-expression signatures in breast cancer. N Engl J Med 2009; 360:790800; PMID:19228622; http://dx.doi.org/10.1056/ NEJMra0801289

10. Tomás G, Tarabichi M, Gacquer D, Hébrant A, Dom G, Dumont JE, Keutgen X, Fahey TJ 3rd, Maenhaut C, Detours V. A general method to derive robust organ-specific gene expression-based differentiation indices: application to thyroid cancer diagnostic. Oncogene 2012; 31:4490-8; PMID:22266856; http://dx.doi.org/10.1038/onc.2011.626
11. Raspe E, Decraene C, Berx G. Gene expression profiling to dissect the complexity of cancer biology: pitfalls and promise. Semin Cancer Biol 2012; 22:250-60; PMID:22459768; http://dx.doi. org/10.1016/j.semcancer.2012.02.011

12. Prat A, Ellis MJ, Perou CM. Practical implications of gene-expression-based assays for breast oncologists. Nat Rev Clin Oncol 2012; 9:48-57; PMID:22143140; http://dx.doi.org/10.1038/nrclinonc.2011.178

13. Quintana E, Shackleton M, Sabel MS, Fullen DR, Johnson TM, Morrison SJ. Efficient tumour formation by single human melanoma cells. Nature 2008; 456:593-8; PMID:19052619; http://dx.doi. org/10.1038/nature07567

14. Jan M, Majeti R. Clonal evolution of acute leukemia genomes. Oncogene 2013; 32:135-40; PMID:22349821; $\quad$ http://dx.doi.org/10.1038/ onc. 2012.48

15. Almendro V, Marusyk A, Polyak K. Cellular heterogeneity and molecular evolution in cancer. Annu Rev Pathol 2013; 8:277-302; PMID:23092187; http:// dx.doi.org/10.1146/annurev-pathol-020712-163923

16. Floor SL, Dumont JE, Maenhaut C, Raspe E. Hallmarks of cancer: of all cancer cells, all the time? Trends Mol Med 2012; 18:509-15; PMID:22795735; http://dx.doi.org/10.1016/j.molmed.2012.06.005 
17. Sottoriva A, Spiteri I, Piccirillo SG, Touloumis A, Collins VP, Marioni JC, Curtis C, Watts C, Tavaré $\mathrm{S}$. Intratumor heterogeneity in human glioblastoma reflects cancer evolutionary dynamics. Proc Natl Acad Sci U S A 2013; 110:4009-14; PMID:23412337; http://dx.doi.org/10.1073/pnas.1219747110

18. Aparicio S, Caldas C. The implications of clonal genome evolution for cancer medicine. N Engl J Med 2013; 368:842-51; PMID:23445095; http://dx.doi. org/10.1056/NEJMra1204892

19. Kaiser J. The downside of diversity. Science 2013; 339:1543-5; PMID:23539593; http://dx.doi. org/10.1126/science.339.6127.1543

20. Tarabichi M, Antoniou A, Saiselet M, Pita JM, Andry G, Dumont JE, Detours V, Maenhaut C. Systems biology of cancer: entropy, disorder, and selection-driven evolution to independence, invasion and "swarm intelligence". Cancer Metastasis Rev 2013; PMID:23615877; http://dx.doi.org/10.1007/ s10555-013-9431-y

21. van Es JH, Sato T, van de Wetering M, Lyubimova A, Nee AN, Gregorieff A, Sasaki N, Zeinstra L, van den Born M, Korving J, et al. Dll1+ secretory progenitor cells revert to stem cells upon crypt damage. Nat Cell Biol 2012; 14:1099-104; PMID:23000963; http:// dx.doi.org/10.1038/ncb2581

22. Yamanaka S, Blau HM. Nuclear reprogramming to a pluripotent state by three approaches. Nature 2010; 465:704-12; PMID:20535199; http://dx.doi. org/10.1038/nature09229

23. Quintana E, Shackleton M, Foster HR, Fullen DR, Sabel MS, Johnson TM, Morrison SJ. Phenotypic heterogeneity among tumorigenic melanoma cells from patients that is reversible and not hierarchically organized. Cancer Cell 2010; 18:510-23, PMID:21075313; $\quad$ http://dx.doi.org/10.1016/j. ccr.2010.10.012

24. Gupta PB, Fillmore CM, Jiang G, Shapira SD, Tao K, Kuperwasser C, Lander ES. Stochastic state transitions give rise to phenotypic equilibrium in populations of cancer cells. Cell 2011; 146:63344; PMID:21854987; http://dx.doi.org/10.1016/j. cell.2011.07.026

25. Chaffer CL, Brueckmann I, Scheel C, Kaestli AJ, Wiggins PA, Rodrigues LO, Brooks M, Reinhardt F, Su Y, Polyak K, et al. Normal and neoplastic nonstem cells can spontaneously convert to a stem-like state. Proc Natl Acad Sci U S A 2011; 108:79505; PMID:21498687; http://dx.doi.org/10.1073/ pnas. 1102454108

26. Ischenko I, Zhi J, Moll UM, Nemajerova A, Petrenko O. Direct reprogramming by oncogenic Ras and Myc. Proc Natl Acad Sci U S A 2013; 110:393742; PMID:23431158; http://dx.doi.org/10.1073/ pnas. 1219592110

27. Brabletz T, Jung A, Spaderna S, Hlubek F, Kirchner T. Opinion: migrating cancer stem cells - an integrated concept of malignant tumour progression. Nat Rev Cancer 2005; 5:744-9; PMID:16148886; http:// dx.doi.org/10.1038/nrc1694

28. Weinberg RA. Twisted epithelial-mesenchymal transition blocks senescence. Nat Cell Biol 2008; 10:10213; PMID:18758491; http://dx.doi.org/10.1038/ ncb0908-1021

29. Shien K, Toyooka S, Yamamoto H, Soh J, Jida M, Thu KL, Hashida S, Maki Y, Ichihara E, Asano H, et al. Acquired resistance to EGFR inhibitors is associated with a manifestation of stem cell-like properties in cancer cells. Cancer Res 2013; 73:3051-61; PMID:23542356; http://dx.doi.org/10.1158/00085472.CAN-12-4136

30. Floor S, van Staveren WC, Larsimont D, Dumont JE, Maenhaut C. Cancer cells in epithelial-to-mesenchymal transition and tumor-propagating-cancer stem cells: distinct, overlapping or same populations. Oncogene 2011; 30:4609-21; PMID:21643013; http://dx.doi.org/10.1038/onc.2011.184
31. Li L, Clevers H. Coexistence of quiescent and active adult stem cells in mammals. Science 2010; 327:542 5; PMID:20110496; http://dx.doi.org/10.1126/ science. 1180794

32. Biddle A, Mackenzie IC. Cancer stem cells and EMT in carcinoma. Cancer Metastasis Rev 2012; PMID:22302111; $\quad$ http://dx.doi.org/10.1007/ s10555-012-9345-0

33. Li X, Lewis MT, Huang J, Gutierrez C, Osborne CK, Wu MF, Hilsenbeck SG, Pavlick A, Zhang X, Chamness GC, et al. Intrinsic resistance of tumorigenic breast cancer cells to chemotherapy. J Nat Cancer Inst 2008; 100:672-9; PMID:18445819; http://dx.doi.org/10.1093/jnci/djn123

34. Medema JP. Cancer stem cells: the challenges ahead. Nat Cell Biol 2013; 15:338-44; PMID:23548926; http://dx.doi.org/10.1038/ncb2717

35. Beck B, Driessens G, Goossens S, Youssef KK, Kuchnio A, Caauwe A, Sotiropoulou PA, Loges S, Lapouge $G$, Candi A, et al. A vascular niche and a VEGF-Nrp1 loop regulate the initiation and stemness of skin tumours. Nature 2011; 478:399-403; PMID:22012397; $\quad$ http://dx.doi.org/10.1038/ nature 10525

36. Croker AK, Goodale D, Chu J, Postenka C, Hedley BD, Hess DA, Allan AL. High aldehyde dehydrogenase and expression of cancer stem cell markers selects for breast cancer cells with enhanced malig nant and metastatic ability. J Cell Mol Med 2009; 13(8B):2236-52; PMID:18681906; http://dx.doi. org/10.1111/j.1582-4934.2008.00455.x

37. Atkinson RL, Yang WT, Rosen DG, Landis MD, Wong $\mathrm{H}$, Lewis MT, Creighton CJ, Sexton KR, Hilsenbeck SG, Sahin AA, et al. Cancer stem cell markers are enriched in normal tissue adjacent to triple negative breast cancer and inversely correlated with DNA repair deficiency. Breast Cancer Res 2013; 15:R77; PMID:24008095; http://dx.doi. org/10.1186/bcr3471

38. Blanpain C, Fuchs E. Epidermal stem cells of the skin. Annu Rev Cell Dev Biol 2006; 22:339-73, PMID:16824012; $\quad$ http://dx.doi.org/10.1146/ annurev.cellbio.22.010305.104357

39. Blagosklonny MV. Cancer stem cell and cancer stemloids: from biology to therapy. Cancer Biol Ther 2007; 6:1684-90; PMID:18344680; http://dx.doi. org/10.4161/cbt.6.11.5167

40. Blagosklonny MV. Target for cancer therapy: proliferating cells or stem cells. Leukemia 2006; 20:385 91; PMID:16357832; http://dx.doi.org/10.1038/ sj.leu. 2404075

41. Hu L, McArthur C, Jaffe RB. Ovarian cancer stem-like side-population cells are tumourigenic and chemoresistant. Br J Cancer 2010; 102:1276 83; PMID:20354527; http://dx.doi.org/10.1038/ sj.bjc. 6605626

42. Clément V, Marino D, Cudalbu C, Hamou MF, Mlynarik V, de Tribolet N, Dietrich PY, Gruetter R, Hegi ME, Radovanovic I. Marker-independent identification of glioma-initiating cells. Nat Methods 2010; 7:224-8; PMID:20173750; http://dx.doi. org/10.1038/nmeth.1430

43. Malaise EP, Chavaudra N, Tubiana M. The relationship between growth rate, labelling index and histological type of human solid tumours. Eur J Cancer 1973; 9:305-12; PMID:4360278; http://dx.doi. org/10.1016/0014-2964(73)90099-6

44. Chen J, Li Y, Yu TS, McKay RM, Burns DK, Kernie SG, Parada LF. A restricted cell population propagates glioblastoma growth after chemotherapy. Nature 2012; 488:522-6; PMID:22854781; http:// dx.doi.org/10.1038/nature11287

45. Driessens G, Beck B, Caauwe A, Simons BD, Blanpain C. Defining the mode of tumour growth by clonal analysis. Nature 2012; 488:527-30; PMID:22854777; http://dx.doi.org/10.1038/ nature11344
46. Schepers AG, Snippert HJ, Stange DE, van den Born $M$, van Es JH, van de Wetering $M$, Clevers $H$. Lineage tracing reveals Lgr5+ stem cell activity in mouse intestinal adenomas. Science 2012; 337:7305; PMID:22855427; http://dx.doi.org/10.1126/ science. 1224676

47. Yang J, Weinberg RA. Epithelial-mesenchymal transition: at the crossroads of development and tumor metastasis. Dev Cell 2008; 14:818-29; PMID:18539112; $\quad$ http://dx.doi.org/10.1016/j. devcel.2008.05.009

48. Elena SF, Lenski RE. Test of synergistic interactions among deleterious mutations in bacteria. Nature 1997; 390:395-8; PMID:9389477; http://dx.doi. org $/ 10.1038 / 37108$

49. Eyre-Walker A, Keightley PD. The distribution of fitness effects of new mutations. Nat Rev Genet 2007; 8:610-8; PMID:17637733; http://dx.doi. org/10.1038/nrg2146

50. Boyer LA, Plath $\mathrm{K}$, Zeitlinger J, Brambrink $\mathrm{T}$, Medeiros LA, Lee TI, Levine SS, Wernig M, Tajonar A, Ray MK, et al. Polycomb complexes repress developmental regulators in murine embryonic stem cells. Nature 2006; 441:349-53; PMID:16625203; http:// dx.doi.org/10.1038/nature 04733

51. Barrett LE, Granot Z, Coker C, Iavarone A, Hambardzumyan D, Holland EC, Nam HS, Benezra R. Self-renewal does not predict tumor growth potential in mouse models of high-grade glioma. Cancer Cell 2012; 21:11-24; PMID:22264785; http:// dx.doi.org/10.1016/j.ccr.2011.11.025

52. Brabletz T. To differentiate or not--routes towards metastasis. Nat Rev Cancer 2012; 12:425-36; PMID:22576165; $\quad$ http://dx.doi.org/10.1038/ nrc3265

53. Sugihara E, Saya H. Complexity of cancer stem cells. Int J Cancer 2013; 132:1249-59; PMID:23180591; http://dx.doi.org/10.1002/ijc. 27961

54. Medema JP, Vermeulen L. Microenvironmental regulation of stem cells in intestinal homeostasis and cancer. Nature 2011; 474:318-26; PMID:21677748; http://dx.doi.org/10.1038/nature10212

55. Magee JA, Piskounova E, Morrison SJ. Cancer stem cells: impact, heterogeneity, and uncertainty. Cancer Cell 2012; 21:283-96; PMID:22439924; http:// dx.doi.org/10.1016/j.ccr.2012.03.003

56. Hanahan D, Weinberg RA. Hallmarks of cancer: the next generation. Cell 2011; 144:646-74; PMID:21376230; http://dx.doi.org/10.1016/j. cell.2011.02.013

57. Shibata M, Shen MM. The roots of cancer: stem cells and the basis for tumor heterogeneity. Bioessays 2013; 35:253-60; PMID:23027425; http://dx.doi. org/10.1002/bies.201200101

58. Clarke MF, Dick JE, Dirks PB, Eaves CJ, Jamieson $\mathrm{CH}$, Jones DL, Visvader J, Weissman IL, Wah GM. Cancer stem cells--perspectives on current status and future directions: AACR Workshop on cancer stem cells. Cancer Res 2006; 66:9339-44; PMID:16990346; http://dx.doi.org/10.1158/00085472.CAN-06-3126

59. Lang JY, Shi Y, Chin YE. Reprogramming cancer cells: back to the future. Oncogene 2013; 32:22478; PMID:22869153; http://dx.doi.org/10.1038/ onc. 2012.349

60. Chang L, Graham PH, Hao J, Ni J, Bucci J, Cozzi PJ, Kearsley JH, Li Y. Acquisition of epithelial-mesenchymal transition and cancer stem cell phenotypes is associated with activation of the PI3K/Akt $/ \mathrm{mTOR}$ pathway in prostate cancer radioresistance. Cell Death Dis 2013; 4:e875; PMID:24157869; http:// dx.doi.org/10.1038/cddis.2013.407 
61. Stieber D, Golebiewska A, Evers L, Lenkiewicz E, Brons NH, Nicot N, Oudin A, Bougnaud S, Hertel F, Bjerkvig R, et al. Glioblastomas are composed of genetically divergent clones with distinct tumourigenic potential and variable stem cell-associated phenotypes. Acta Neuropathol 2013; PMID:24154962; http://dx.doi.org/10.1007/s00401-013-1196-4

62. Visvader JE. Cells of origin in cancer. Nature 2011; 469:314-22; PMID:21248838; http://dx.doi. org/10.1038/nature09781

63. Van Keymeulen A, Rocha AS, Ousset M, Beck B, Bouvencourt G, Rock J, Sharma N, Dekoninck S, Blanpain C. Distinct stem cells contribute to mammary gland development and maintenance. Nature 2011; 479:189-93; PMID:21983963; http://dx.doi. org/10.1038/nature10573
64. Hong D, Gupta R, Ancliff P, Atzberger A, Brown J, Soneji S, Green J, Colman S, Piacibello W, Buckle $\mathrm{V}$, et al. Initiating and cancer-propagating cells in TEL-AML1-associated childhood leukemia. Science 2008; 319:336-9; PMID:18202291; http://dx.doi. org/10.1126/science. 1150648

65. Weis SM, Cheresh DA. A wake-up call for hibernating tumour cells. Nat Cell Biol 2013; 15:721 3; PMID:23817234; http://dx.doi.org/10.1038/ ncb2794

66. Ghajar CM, Peinado H, Mori H, Matei IR, Evason KJ, Brazier H, Almeida D, Koller A, Hajjar KA Stainier DY, et al. The perivascular niche regulates breast tumour dormancy. Nat Cell Biol 2013; 15:80717; PMID:23728425; http://dx.doi.org/10.1038/ ncb2767
67. Mani SA, Guo W, Liao MJ, Eaton EN, Ayyanan A, Zhou AY, Brooks M, Reinhard F, Zhang CC, Shipitsin M, et al. The epithelial-mesenchymal transition generates cells with properties of stem cells. Cell 2008; 133:704-15; PMID:18485877; http://dx.doi. org/10.1016/j.cell.2008.03.027

68. Morel AP, Lièvre M, Thomas C, Hinkal G, Ansieau S, Puisieux A. Generation of breast cancer stem cells through epithelial-mesenchymal transition. PLoS One 2008; 3:e2888; PMID:18682804; http:// dx.doi.org/10.1371/journal.pone.0002888 